\title{
Correction to: Systematic review of invasive meningococcal disease epidemiology in the Eastern Mediterranean and North Africa region
}

Alp Giray Dogu', Anouk M. Oordt-Speets², Femke van Kessel-de Bruijn², Mehmet Ceyhan³ and Amine Amiche ${ }^{1 *}$

\section{Correction to: BMC Infect Dis (2021) 21:1088}

https://doi.org/10.1186/s12879-021-06781-6

Following the publication of the original article [1], some errors were identified in the text and in Table 3a.

The footnotes are currently labeled as:

a Surveillance study.

b Meningeal irritation syndrome encompasses Kernig's sign and Brudzinski's sign.

The footnotes should be labeled as:

A Meningeal irritation syndrome encompasses Kernig's sign and Brudzinski's sign B Surveillance study.

The original article [1] has been corrected.

\section{Author details}

${ }^{1}$ Sanof Pasteur, Dubai, UAE. ${ }^{2}$ Pallas, Rotterdam, The Netherlands. ${ }^{3}$ Faculty of Medicine, Hacettepe University, Ankara, Turkey.

Published online: 15 November 2021

Reference

1. Dogu AG, Oordt-Speets AM, van Kessel-de BF, Ceyhan M, Amiche A. Systematic review of invasive meningococcal disease epidemiology in the Eastern Mediterranean and North Africa region. BMC Infect Dis. 2021;21:1088. https://doi.org/10.1186/s12879-021-06781-6.

\section{Publisher's Note}

Springer Nature remains neutral with regard to jurisdictional claims in published maps and institutional affiliations.

(c) The Author(s) 2021. Open Access This article is licensed under a Creative Commons Attribution 4.0 International License, which permits use, sharing, adaptation, distribution and reproduction in any medium or format, as long as you give appropriate credit to the original author(s) and the source, provide a link to the Creative Commons licence, and indicate if changes were made. The images or other third party material in this article are included in the article's Creative Commons licence, unless indicated otherwise in a credit line to the material. If material is not included in the article's Creative Commons licence and your intended use is not permitted by statutory regulation or exceeds the permitted use, you will need to obtain permission directly from the copyright holder. To view a copy of this licence, visit http://creativecommons.org/licenses/by/4.0/. The Creative Commons Public Domain Dedication waiver (http://creativecommons.org/publicdomain/zero/1.0/) applies to the data made available in this article, unless otherwise stated in a credit line to the data. 